\title{
Sexual advice at a Federal University
}

\section{Aconselhamento sexual numa instituição federal de ensino superior}

\author{
Maria Angélica Aires Gil ${ }^{1}$, Andréa Carla Oliveira ${ }^{2}$, Erica Aires Gil ${ }^{3}$
}

1. Master in institutional processes management for Federal University of Rio Grande do Norte, Brazil.

2. Master in psychology for Federal University of Rio Grande do Norte, Brazil

3. Master in pharmacy for pela Federal University of Rio Grande do Norte, Brazil.

Study performed at Federal University of Rio Grande do Norte, Brazil.

Financial support: None.

Conflict of interest: None.

Correspondence address: E-mail: mariaangelicaairesgil@gmail.com

Submitted: December 11, 2017. Accepted, after review: December 20, 2017.

\begin{abstract}
Purpose: The incidence of Sexually Transmitted Infections (STIS), a serious health problem, remains very high in Brazil, especially for the Human Immunodeficiency Virus (HIV), which has mobilized governments and the scientific community to control them. Sex education should be the primary means of preventing STIs by adopting strategies tailored to each population. The objective was to analyze the profile of individuals who seek sexual counseling at the Federal University of Rio Grande do Norte (UFRN) in Natal, Rio Grande do Norte state. Methods: The study used a quantitative approach, descriptive longitudinal design, and data collection with proportional stratified sampling, totaling 98 self-reporting questionnaires. Results: Participants exhibited the following profile: the majority were single heterosexual young men with secondary schooling. Thirty participants reported having had only one sexual partner and 81 had never contracted any STIs. Conclusion: It is concluded that the subjects who seek sexual counseling practice safe sex and need to be encouraged to undergo HIV testing.
\end{abstract}

Key words: Sexually Transmitted Infections (STIs). Disease prevention. See Education. 


\section{RESUMO}

Objetivo: A incidência de Infecções Sexualmente Transmissíveis (IST) ainda é muito alta no Brasil, especialmente à infecção pelo Vírus da Imunodeficiência Humana (HIV), o que tem mobilizado governo e comunidade científica para o controle dessas infecções, pois se trata de um grave problema de saúde pública. A educação sexual deve ser o principal meio para trabalhar a prevenção sexual sob formas e estratégias adaptadas a cada população. O objetivo foi analisar o perfil dos sujeitos que buscam um projeto de aconselhamento sexual na Universidade Federal do Rio Grande do Norte (UFRN). Métodos: Com aborda gem quantitativa, delineamento descritivo longitudinal, do tipo levantamento de dados com amostragem estratificada proporcional, totalizando 98 questionários autoaplicados. Os participantes apresentaram o seguinte perfil: maioria de homens, jovens e adultos, com ensino médio completo, solteiros, heterossexuais. Resultados: Os resultados demonstraram que um número significativo da amostra 30 participantes só tiveram um parceiro sexual e 81 nunca contraíram nenhuma IST. Conclusão: Conclui-se que os sujeitos que buscam o projeto têm práticas sexuais seguras e necessitam de estímulos à testagem de HIV.

Descritores: Infeç̧ões Sexualmente Transmissíveis (IST). Prevenção de Doenças. Educação Sexual.

\section{INTRODUCTION}

The populations most vulnerable to contracting the virus are poorly informed individuals and those without comprehensive health care. Good quality of life encompasses several health promotion factors that may favor a more dignified life in all its aspects, including access to education, sociocultural life, work and leisure, among others ${ }^{1}$.

Information alone is insufficient to achieve a change in attitude. Several behaviors are rooted in complex issues, and the fact is, individuals, including university students, deny the possibility of contracting the HIV virus, believing they are armed with sufficient knowledge and, as such, are immune ${ }^{2}$.

There are a number of studies relating AIDS to different social categories; however, research on university students should be encouraged and the few studies that were found indicate they use condoms infrequently or only as a contraceptive. 
There seem to be gaps in understanding STI/HIV transmission and individuals in this age group do not perceive their vulnerability.

Understanding how young people view and conduct their sex life is an important factor in carrying out preventive studies, since failure to do so has led to prevention strategies that either contain difficult-to-understand metaphorical language, or vulgarize the issue, resulting in stigma or prejudice ${ }^{3}$.

The extension project denominated the Health Advice Program (PAS) was instituted in 2013, and had counseled 2831 individuals by 2015, primarily through sex education for students and staff of the Federal University of Rio Grande do Norte (UFRN). These sessions revealed that unprotected sex was widespread. Many did not use condoms and those who did used them improperly or only occasionally.

The research field selected was the UFRN due to the large number of sexually active students aged between 18 and 24 years, a group that, according to recent studies, accounts for $42 \%$ of new HIV cases worldwide. Preventive measures have not been effective in changing attitudes ${ }^{4}$.

Thus, the present study traced the profile of program users, analyzing the sexual behaviors that make them vulnerable.

The relevance of this investigation lies in the possibility of collecting data to develop indicators to monitor the STI/HIV epidemic in terms of prevention and control measures, in addition to creating strategies to enhance knowledge on STIS/HIV/AIDS and improve attitudes, behaviors and prevention practices in the UFRN community.

\section{METHODS}

This quantitative, longitudinal descriptive study collected data from 98 selfreporting questionnaires.

The questionnaire, which contains 8 questions devised specifically for the present study, was inspired by previously developed and validated instruments $5,6,7,8,9$. Participants were recruited by spontaneous demand at the program enrolment center. After answering the questions, the men received condoms and the women contraceptives and lubricant. The questionnaire sought to characterize the profile of the individuals who enrolled in the project. 
The study is descriptive since it attempts to identify the profile of a particular population, which also characterizes it as social research in that it attempts to mirror an effective intervention as much as possible. In this type of study, the characteristics of a specific population are investigated using standard data collection procedures, such as the structured questionnaire applied here ${ }^{10}$.

In most descriptive studies, survey data collection is the most widely used method, since the aim is to determine the behaviors of a certain group of people and conduct quantitative analysis ${ }^{10}$. The intimate nature of the issue and questions posed no significant difficulties. However, online application reached a larger number of subjects in a short time frame.

According to ${ }^{11}$, the survey can be used to generalize the questions collected from a sample of the population in the case of longitudinal design over a 4-year period between 2013 and 2017.

The following inclusion criteria were established:

- Students enrolled in traditional or distance courses;

- Active staff, professors and technical-administrative personnel at the central campus of Natal, Rio Grande do Norte state, characterizing a random sample.

The questionnaire contained questions on the following aspects: age, sex, marital status, sexual orientation, number of sexual partners, and whether they had been tested for HIV and syphilis, or contaminated by any STI.

The information collected was analyzed using descriptive and inferential statistics (chi-squared and student's t-tests), in line with parametric and nonparametric data distribution.

These percentages were used for data analysis considering the vulnerability of participants' sexual health in order to trace the profile of project users.

\section{RESULTS}

The 98 subjects exhibited the following profile: majority of men (67.3\%), ages ranging between 19 and 60 years with most in the 24 to 28-year age group (54\%), and predominantly (64.2\%) single (Tables 1, 2 and 3). 
Table 1 - Sex

\begin{tabular}{c|c}
\hline Sex & Number \\
\hline Female & 32 \\
\hline Male & 66 \\
\hline
\end{tabular}

Source: research data (2017).

Table 2 - Age

\begin{tabular}{|c|c|}
\hline Age & Number \\
\hline 60 years & 1 \\
\hline 55 years & 1 \\
\hline 43 years & 1 \\
\hline 41 years & 2 \\
\hline 40 years & 1 \\
\hline 38 years & 3 \\
\hline 36 years & 3 \\
\hline 35 years & 2 \\
\hline 33 years & 2 \\
\hline 30 years & 4 \\
\hline 32 years & 3 \\
\hline 31 years & 4 \\
\hline 28 years & 12 \\
\hline 27 years & 1 \\
\hline 26 years & 7 \\
\hline 25 years & 7 \\
\hline 24 years & 10 \\
\hline 23 years & 13 \\
\hline 22 years & 10 \\
\hline 21 years & 2 \\
\hline 20 years & 8 \\
\hline 19 years & 1 \\
\hline
\end{tabular}

Source: research data (2017).

Table 3 - Marital status

\begin{tabular}{c|c}
\hline Marital Status & Number \\
\hline Single & 63 \\
\hline Dating & 14 \\
\hline Engaged & 1 \\
\hline Married & 6 \\
\hline Common-law relationship & 7 \\
\hline Divorced & 3 \\
\hline NR & 4 \\
\hline
\end{tabular}

Source: research data (2017). 
With respect to sexual orientation, most $(72.4 \%)$ stated being heterosexual (Graph 1).

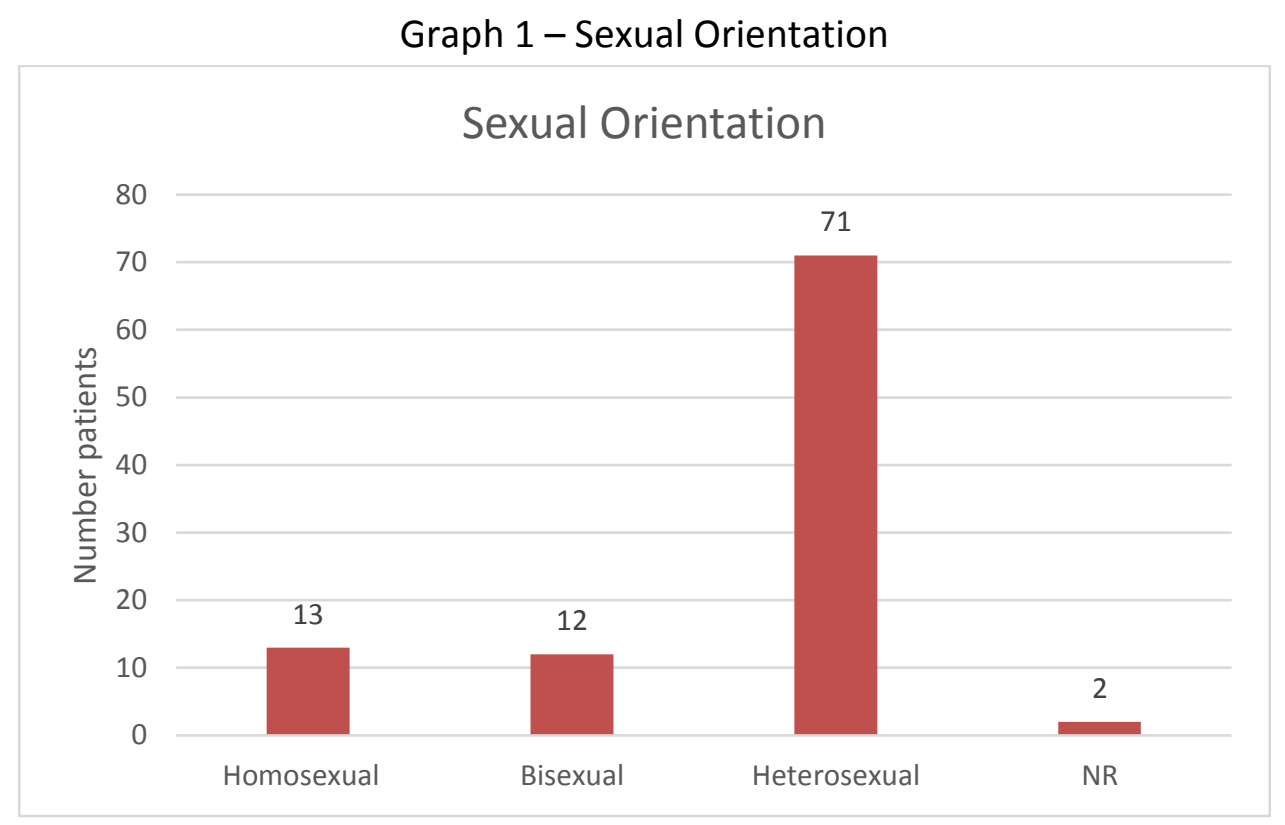

Source: research data (2017).

Since the start of their sexual activity they reported having had between 1 and 300 partners. A predominance of individuals reported having only one partner during their sexual life (30), as shown in Table 4. 
Table 4 - Number of partners

\begin{tabular}{c|c}
\hline Number of partners & Number \\
\hline 0 & 1 \\
\hline 1 & 30 \\
\hline 2 & 3 \\
\hline 3 & 5 \\
\hline 4 & 11 \\
\hline 5 & 5 \\
\hline 6 & 6 \\
\hline 8 & 3 \\
\hline 9 & 2 \\
\hline 10 & 4 \\
\hline 12 & 1 \\
\hline 15 & 3 \\
\hline 20 & 4 \\
\hline 25 & 1 \\
\hline More than 20 & 1 \\
\hline Fewer than 50 & 3 \\
\hline 50 & 2 \\
\hline More than 60 & 1 \\
\hline More than 100 & 2 \\
\hline 200 & 1 \\
\hline More than 300 & 1 \\
\hline NR & 8 \\
\hline Source: research data $(2017)$. \\
\hline 200
\end{tabular}

With respect to having been tested for HIV and syphilis, the sample was evenly divided, 49 responding yes and 47 no (Graph 2). 
Graph 2 - Rapid HIV test

\section{Rapid HIV test}

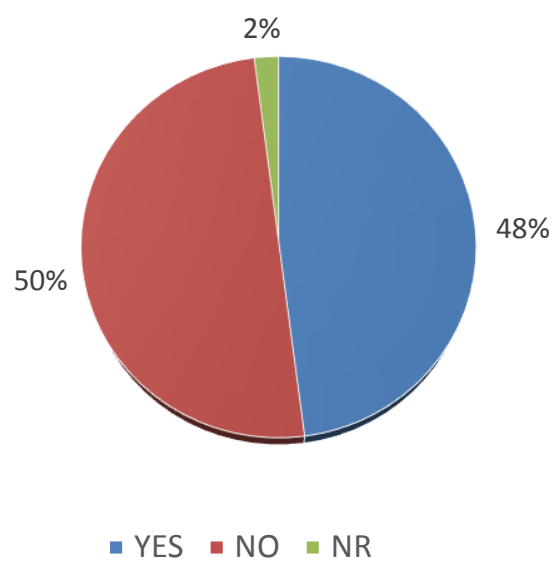

Source: research data (2017).

In regard to STIs, 81 participants reported never having contracted this type of infection (Table 5).

Table 5 - Previous STIs

\begin{tabular}{c|c}
\hline Previous STIs & Number \\
\hline HIV & 0 \\
\hline Gonorrhea & 4 \\
\hline Syphilis & 1 \\
\hline HPV & 1 \\
\hline Hepatitis & 1 \\
\hline Several & 2 \\
\hline Oral herpes & 1 \\
\hline Genital herpes & 2 \\
\hline Candidiasis & 2 \\
\hline None & 81 \\
\hline NR & 3 \\
\hline
\end{tabular}

Source: research data (2017).

\section{DISCUSSION}

According to ${ }^{12,13}$, several of the behaviors identified in this study are affected by age and type of relationship with partners, given that most of the sample is 
composed of single male students aged between 24 and 28 years and their attitudes may change over time.

Report that the concept of vulnerability is related to behaviors individuals acquire that leave them more exposed to HIV infection (unprotected sex, alcohol and drug abuse, blood contact and vertical transmission). However, the concept only makes sense depending on how individuals receive information and act upon it ${ }^{14 .}$

The sample investigated should be tested because sexually active people engage in risky behavior and should be tested annually for HIV and syphilis. The Ministry of Health, in its "Fique Sabendo Sua Sorologia" (Know Your Serology) campaign, conducts rapids tests in many locations and health units are equipped to diagnose the disease in 15 minutes $^{15}$.

Although public policies should promote greater discussion on sexuality aimed at disease prevention, government entities continue to display regressive attitudes that are incompatible with the demands of the population.

Preventing STIs relies primarily on men using condoms, demonstrating the need to educate target populations on other means of avoiding HIV infection, including preexposure prophylaxis (PREP), post-exposure prophylaxis (PEP), HIV testing and prevention campaigns and the vertical transmission protocol.

The university community showed a different profile to that exhibited by the general population in terms of vulnerability to STIS/HIV/AIDS, since they report few sexual partners, low frequency of STIs and occasional HIV and syphilis testing.

Despite being a wide-ranging problem, disease prevention at universities needs to be promoted in order to decrease STIs in young adults.

\section{REFERENCES}

1. Paiva V, França Júnior I, Kalichman, AO. Vulnerabilidade e direitos humyears: prevenção e promoção da saúde, planejar, fazer e avaliar. Curitiba: Juruá; 2013.

2. Gir E, et al. Avaliação dos riscos da infecção pelo HIV segundo diferentes práticas sexuais na perspectiva de estudantes universitários e especialistas em HIV/AIDS. Rev Esc Enf USP.1999; 33(1):4-16. 
3. Brandão ER, Heilborn ML. Sexualidade e gravidez na adolescência entre jovens de camadas médias do Rio de Janeiro, Brasil. Cad Saúde Pública. 2006; 22(7):14211430 .

4. Pereira BS et al. Fatores associados à infecção pelo HIV/AIDS entre adolescentes e adultos jovens matriculados em Centro de Testagem e Aconselhamento no Estado da Bahia, Brasil. Ciên Saúde Colet. 2014;19(3):747-58.

5. Moriya TM, Gir E, Hayashida M. Escala de atitude frenta à Aids: uma análise psicométrica. Rev Latino-am Enferm.1994; 2(2):39-53.

6. Brasil. Pesquisa de conhecimentos, atitudes e práticas na população brasileira PCAP. Secretaria de Vigilância em Saúde. Departamento de DST, Aids e Hepatites Virais. Ministério da Saúde. Portal da saúde. Brasília; 2011.

7. Brasil. Eu preciso fazer o teste de HIV/Aids. Brasília: Ministério da Educação. Ministério da Saúde. [Internet]. 2016 [cited 2016 Mar. 10]. Available from: http://www.unicef.org/brazil/pt/arquivoteste.pdf

8. Vasconcelos DC, Coêlho AEL. Conhecimentos, atitudes e percepção de risco dos acadêmicos de Farmácia frente à Aids. Rev Psicol Saúde. 2013; 5(2).109-17.

9. Camargo BV, Barbará A, Bertoldo R. Um instrumento de medida da dimensão Informativa da Representação Social da aids. In: 4o Jornada Internacional Conferência brasileira sobre representações sociais: Teoria e Abordagens Metodológicas, 2005; João Pessoa.

10. Gil AC. Como elaborar projetos de pesquisa. 4. ed. São Paulo: Atlas; 2009.

11. Creswell JW. Projeto de pesquisa: métodos qualitativo, quantitativo e misto. 3. ed. Porto Alegre: Artmed; 2010.

12. Michener HA, Delamatier JD, Myers DJ. Psicologia social. São Paulo: Pioneira; 2005.

13. Falcão JSP. et al. Perfil e práticas sexuais de universitários da área de saúde. Esc Anna Nery R Enferm. 2007;11 (1): 58-65.

14. Silva $C M$, Vargens, OMC. A percepção de mulheres quanto à vulnerabilidade feminina para contrair DST/HIV. Rev Esc Enferm USP. 2009;43(2):401-6.

15. Joint United Nations Program on HIV/AIDS. Tratamento [Internet].2015 [ cited 2018 Abr.17]. Available from: https://unaids.org.br/wpcontent/uploads/2016/03/Tratamento-2015.pdf 